\title{
The Course of Intelligence of Pasture Fishery
}

\author{
Mukhachev Igor Semenovich* \\ Doctor of Biological Sciences, State Agrarian University of the Northern Trans-Urals, Russia
}

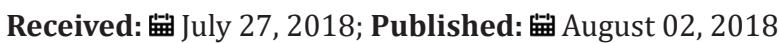

*Corresponding author: Mukhachev Igor Semenovich, Doctor of Biological Sciences, State Agrarian University of the Northern TransUrals, Tyumen, Russia

\section{Mini Review}

In modern Russia, the cultivation of commercial fish in lakes for grazing (foraging) technology is transformed from an extensive form of production into an intensive one with elements of industrialization. Year after year, more and more large and small lake fish farms and farms are mastering new technologies for ameliorating the aquatic environment and modern biotechnologists for growing commercial fish. This occurs on the basis of understanding by users of reservoirs of the real benefits of modernization, which significantly improves the effectiveness of fish breeding hydronomy, combining the processes of agronomy and animal husbandry [1] on natural and artificial reservoirs. Thanks to the technological methods of melioration, lakes become the base for a multiple increase in catches of fish by methods of fish farming in the calculation of 1 hectare, since natural biological properties of water bodies are more efficiently used. On the territory of Russia, in the forest-steppe zone from the Ural Mountains to the Yenisey River, there are many different types of lakes, both in area and in terms of hydrobiological indicators.

In this region, along with undeveloped lakes (depths of more than 7-8 m), a large number of lakes with smaller depths are concentrated (overseas lakes with depths of 2-5 m), where periodically in winter (in shallow years) there is an oxygen deficit and local fish die [2-4]. The average annual catch rate of local fish in the lakes of the crucian and roach-perch ichthyological types in the forest-steppe zone is usually $25-35 \mathrm{~kg} / \mathrm{ha}$. And such commercial catch of low-value fish does not bring significant economic and economic results. In the preceding years [5], in the subjects of the Federation, lacustrine commodity fish farms emerged in which, on the basis of melioration of lakes and the introduction of polyculture of fast-growing fish (whitefish, carp, herbivorous, pike perch, etc.), $80-130 \mathrm{~kg} /$ ha per year were grown and even more. However, these economic indicators only partially use the possibilities of natural bioproducts of the forest-steppe lakes of the Trans-Urals and Western Siberia [6]. At present, according to the recommendations of the zonal fishery science, practical work is carried out on the basis of fish-reclamation teams. For example, in the fish farm "Balyk" of the Chelyabinsk region, the fish farm "Siberian theme" of the Kurgan region, the Sladkovo and Kazan fish farms of the Tyumen region began to loosen bottom sapropel deposits in the summer and autumn and involve the mineral and biological components in the intensive bio-production process.

This melioration of lakes contributes to a multiple increase in the production of plankton, an improvement in the development of zoobenthos, which ultimately increases the growth rate of the farmed fish, and, most importantly, the catches increase 5-8 times compared to the previous extensive practice. In fish farms of different thicknesses on the shore of feeding lakes, they began to build out ponds that complement the water-satellite, a kind of wintering complex in the lake of the overseas type (Figure 1). Thanks to a small water reservoir, a depth of 7-8 $\mathrm{m}$, in which a turboaerator with a power of 3-4 kW is installed, all the grown fish is quickly taken with the use of a turboaerator, the young are retained for a subsequent growing season, and there is the possibility of installing cages for pontoons for industrial fish farming, very highly economically stimulating pasture fisheries. The trend of intensification of fish farming on lakes of the overseas type is well represented on the example of Lake Tishki of the fish farm "Balyk" (Table 1) of the Chelyabinsk region.

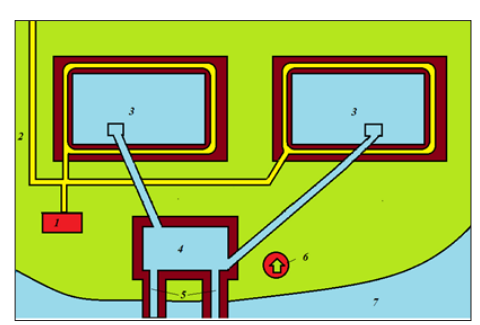

Figure 1: Scheme of ameliorative hydraulic engineering arrangement of a lake of a seaside type with an aquatorium of more than 200 hectares, with the aim of creating a highly productive fish farm: 1 - a fish hatchery; 2 - travel for vehicles and necessary equipment; 3 - Growing ponds with an area of 2-3 hectares with spillways; 4 - water reservoir with a depth of $7 \mathrm{~m} ; 5$ - connecting the channels of the reservoir with the lake; 6 - pumping station for supplying water to the growing ponds. 
Table 1: The dynamics of fish catches in the lake. Tishki (2550 hectares) of the Kunashak district Chelyabinsk region, kg/ ha.

\begin{tabular}{|c|c|c|c|c|c|c|c|c|c|c|c|}
\hline \multirow[b]{2}{*}{ A fish } & \multicolumn{11}{|c|}{ Years } \\
\hline & 1958-1965* & 1966-1970* & 1971-1998* & 1999-2000* & $\begin{array}{l}2001- \\
2005 *\end{array}$ & $\begin{array}{l}\text { 2006- } \\
2012 *\end{array}$ & 2013 & 2014 & 2015 & 2016 & 2017 \\
\hline Crucian & 19,0 & 21,0 & 12,0 & 9,0 & 21,0 & 10,0 & 8,0 & 11,0 & 23,0 & 24,0 & 23,1 \\
\hline \multicolumn{12}{|l|}{ Carp } \\
\hline & - & - & - & - & 10,0 & 99,0 & 85,0 & 90,0 & 99,0 & 89,0 & 39,5 \\
\hline $\begin{array}{c}\mathrm{P} / \\
\text { poison* } \\
*\end{array}$ & - & - & - & - & - & 2,0 & 4,0 & 5,0 & 8,0 & 6,0 & 4,7 \\
\hline Pelyad & - & 24,0 & 36,0 & 66,0 & 85,0 & 115,0 & 118,0 & 121,0 & 111,0 & 119,0 & 96,4 \\
\hline Total & 19,0 & 45,0 & 48,0 & 78,0 & 116,0 & 226,0 & 226,0 & 227,0 & 241,0 & 238,0 & 167,7 \\
\hline
\end{tabular}

*average annual catches for the specified period; * *herbivorous - white cupid, white carp

From the data of the table it is clear that while the herbivorous fish are grown very little due to a lack of planting material. Commissioning of the zonal fish hatchery of herbivorous fish will increase the catches of commercial fish by $150-200 \mathrm{~kg} / \mathrm{ha}$ per year, and not only in this fish farm, but everywhere else on other reservoirs.The development of a zonal fishery science in fisheries management of eutrophic lakes of crucian and densely-percinative ichthyological types (multiple loosening of bottom sediments during open water, aeration of water in winter on the basis of concentration of farmed fish in the aerated zone, introduction of denser plantings of juvenile polyculture provide the basis for integrated intensive technologies that more fully use the natural self-renewable fodder base of reservoirs by objects of commodity cultivation. Developments of scientists early 21st century [7-13] provide a real basis for the large-scale introduction of industrial technologies of lake fish farming within the above-mentioned region of Russia, which allow to receive $300-400 \mathrm{~kg} /$ ha per 1 year of valuable fish.

\section{References}

1. Bormakin EV (1967) On the research of fishery conversion of lakes by chemical method. Izvestiya GOSNIORH 64C: 5-18.

2. Shnitnikov AV (1969) Intra-century variability of components of general moisture. L Science p. 245.

3. Popolzin AG (1967) Lakes of the south of the Ob-Irtysh basin. Novosibirsk: Zap Sib Book, p. 350.
4. Yadrenkina EN (2007) Structure of communities of overseas lakes in the south of Western Siberia. Lake ecosystems: biological processes, anthropogenic transformation, water quality: Proceedings of the international conference. Minsk p. 300.

5. Mukhachev IS, Burdiyan BG, Kugaevskaya LV (1977) The experience of commercial fish farming in the lakes of Tyumen and neighboring regions. Overview information TSNIITEirkh. Fisheries research series. Вып 3100с.

6. Mukhachev IS (2013) Lakeland commercial fish breeding SPb: “Lan" p. 400 s.

7. Alimov AF (2001) Elements of the theory of the functioning of aquatic ecosystems. SPb: Science p. 147.

8. Alimov AF (2016) Once again about ecology. M SPb: Association of Scientific Publications KMK p. 62

9. Servetnik GE (2004) Ways of development of agricultural reservoirs. M: VNIIR p.129

10. Lvov Yu B Cluster fish farming as a way to increase the intensity of fish production. Vestnik ASTU. Series: Fisheries 4: 109-120.

11. Kopylov AI, Kosolapov DB (2011) Microbial "loop" in plankton communities of marine and freshwater ecosystems. Izhevsk: KnigoGrad p. 332.

12. Sigareva LE (2012) Chlorophyll in the bottom sediments of the Volga reservoirs. Moscow: Association of Scientific Publications KMK -217 3(3): 240-248.

13. Sorgeloos P (2013) Aquaculture: the Blue Biotechnology of the Future. World Aquaculture p. 16-31.
ISSN: 2574-1241

DOI: 10.26717/BJSTR.2018.07.001524

Mukhachev Igor Semenovich. Biomed J Sci \& Tech Res

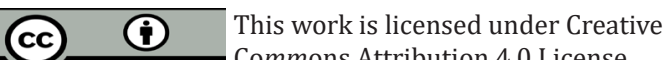

Submission Link: https://biomedres.us/submit-manuscript.php

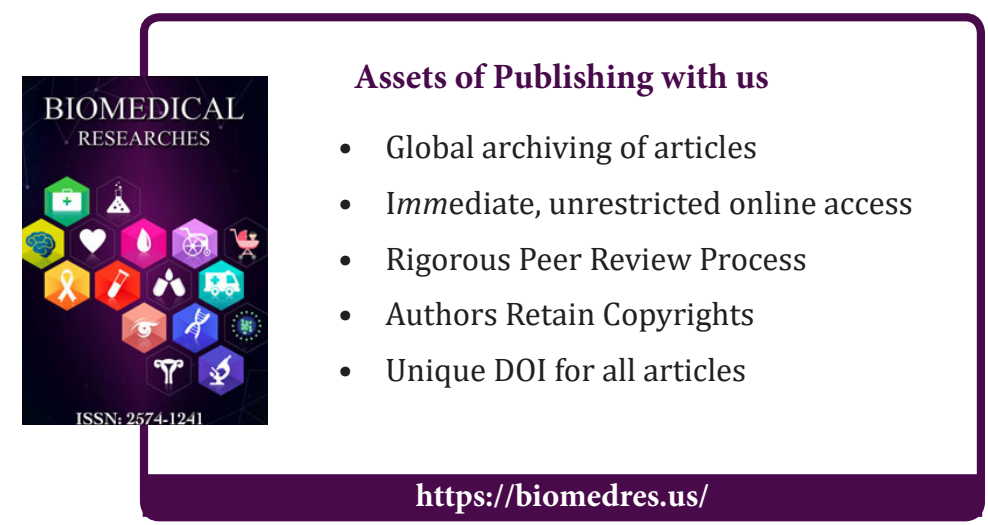

